\title{
POTENSI DEBIT ALIRAN LOKAL WADUK SAGULING MENGGUNAKAN MODEL HUJAN LIMPASAN
}

\section{THE LOCAL POTENTIAL FLOW AT SAGULING RESERVOIR USING RAINFALL RUNOFF MODEL}

\author{
Asep Ferdiansyah ${ }^{1)}$ Sri Mulat Yuningsih ${ }^{1)^{*}}$ Mirwan Rofiq G1) Isnan Fauzan A $^{1 \text { ) }}$ \\ ${ }^{1)}$ Balai Litbang Hidrologi dan Tata Air \\ Jl. Ir H Juanda No. 193 Bandung, Jawa Barat, Indonesia 40135 \\ *Coresponden author: srimulatym@gmail.com
}

Diterima: 13 Maret 2019; Direvisi: 07 September 2019; Disetujui: 13 April 2020

\begin{abstract}
Saguling reservoir is one of the three largest reservoirs in the Citarum River Basin. The water source of its reservoir originates from Upper Citarum river basin, with gauging station located in Citarum-Nanjung and local discharge from tributaries around the reservoir. The problem is there is no observation of local discharge from the tributaries, thus its potential is estimated. The purpose of this study is to analyze the potential of local discharge with the Hydrology Engineering Center-Hydrologic Modeling System (HEC-HMS) model. The HEC-HMS Rainfall-runoff method is used for calculating the potential of the local discharge that flows into Saguling resevrvoir. The parameters used in the model are deficit constant (loss parameter), linear reservoir (baseflow parameter), dan lag time (transform parameter). Rainfallrunoff model produced good calibration values for Citarum-Nanjung Gauging Station with $R^{2}$ of 0.8 and the Nash-Sutcliffe efficiency (NSE) value of 0.788. The verification result carried out in Saguling reservoir gives NSE of 0.8343 and $R^{2}$ value of 0.83. The simulation shows that the potential discharge from local river contributes about $21.64 \%$ of the total discharge that enters into the reservoir with monthly dependable flow for power plants, $Q_{80}$ and $Q_{85}$ values at 8,23 $\mathrm{m}^{3} / \mathrm{s}$ and 5,69 $\mathrm{m}^{3} / \mathrm{s}$, respectively. The average discharge of local rivers can generate electricity of $3.89 \mathrm{MW}-162 \mathrm{MW}$.
\end{abstract}

Keywords: Local discharge, rainfall runoff, potential discharge, Saguling reservoir

\section{ABSTRAK}

Waduk Saguling merupakan salah satu dari tiga waduk terbesar yang ada di Daerah Aliran Sungai Citarum. Sumber air Waduk Saguling berasal dari DAS Citarum Hulu dengan pos pengamatan debit di Citarum-Nanjung dan debit lokal dari beberapa sungai sekitar waduk. Permasalahannya adalah tidak ada pengamatan debit lokal di anak sungai tersebut sehingga potensinya diperkirakan. Tujuan dari pengkajian ini adalah melakukan analisis potensi debit lokal dengan model Hydrology Engineering Center-Hydrologic Modeling System (HEC-HMS). Metode hujan limpasan dengan menggunakan HEC-HMS digunakan untuk menghitung potensi debit lokal yang masuk ke Waduk Saguling. Parameter yang digunakan dalam model adalah deficit constant (parameter loss), linear reservoir (parameter baseflow), dan lag time (parameter transform). Model hujan limpasan tersebut menghasilkan nilai kalibrasi yang baik di pos duga air Citarum-Nanjung dengan nilai $R^{2}$ sebesar 0,8 dan nilai Nash-Sutcliffe efficiency (NSE) sebesar 0,788. Hasil verifikasi yang dilakukan di Waduk Saguling mempunyai nilai NSE sebesar 0,8343 dan $R^{2}$ sebesar 0,83. Hasil simulasi menunjukkan potensi debit air dari sungai lokal menyumbangkan 21,64\% dari total debit air yang masuk ke Waduk Saguling dengan nilai debit andalan rata-rata bulanan untuk keperluan pembangkit listrik yaitu $Q_{80}$ dan $Q_{85}$ adalah sebesar 8,23 $\mathrm{m}^{3} / \mathrm{s}$ dan 5,69 $\mathrm{m}^{3} / \mathrm{s}$. Debit rata-rata sungai lokal tersebut dapat membangkitkan listrik sebesar 3,89 MW-162 MW.

Kata kunci: Aliran lokal, hujan limpasan, potensi aliran, waduk Saguling

\section{PENDAHULUAN}

Waduk Saguling terletak di Kabupaten Bandung, Provinsi Jawa Barat pada ketinggian 643 $\mathrm{m}$ di atas permukaan laut. Waduk ini merupakan salah satu dari tiga waduk yang ada di daerah aliran Sungai Citarum, tepatnya berada di $6^{\circ} 54^{\prime} 45^{\prime \prime} \mathrm{LS}$ $107^{\circ} 21^{\prime} 58^{\prime \prime} \mathrm{BT}$. Waduk ini dibangun pada tahun 1986 dengan kapasitas tampung 982 juta $\mathrm{m}^{3}$ untuk menghasilkan tenaga listrik sebesar $700 \mathrm{MW}$. Keberlangsungan pemanfaatan waduk ini perlu diperhatikan, hasil penelitian Bakhtiar, Hadihardaja, dan Hadihardaja (2013) menyatakan debit rata-rata yang masuk ke Waduk Saguling sekitar $90 \mathrm{~m}^{3} / \mathrm{s}$, laju sedimen sekitar 5 juta ton/tahun, dan umur efektif sekitar 50 tahun.

Debit air yang masuk (inflow) ke Waduk Saguling berasal dari sub Daerah Aliran Sungai (DAS) Citarum - Nanjung dan beberapa subDAS anak sungai lokal sekitar waduk. Oleh karena itu, perlu dilakukan pengkajian terhadap seberapa 
besar inflow Waduk Saguling. Pengkajian ini perlu dilakukan karena pemantauan debit air hanya dilakukan di pos duga air Citarum - Nanjung, sedangkan anak sungai lokal di Waduk Saguling (inflow sungai lokal) yang memberikan kontribusi inflow ke Waduk Saguling tidak ada pengamatan. Dengan tidak adanya pengamatan di beberapa anak sungai tersebut, maka besaran inflow dari sungai lokal tidak dapat diketahui secara pasti.

Debit air yang masuk ke waduk selama ini dipantau berdasarkan monitoring tinggi muka air waduk dan dari pos duga air Citarum-Nanjung. Padahal kapasitas waduk saat ini diduga berkurang dari kapasitas semula karena adanya pengendapan sedimen. Salah satu cara yang dilakukan untuk mengetahui aliran sungai lokal dapat didekati dengan analisis hujan limpasan. Kajian ini diharapkan dapat bermanfaat bagi pengelola untuk mengetahui besaran aliran sungai lokal yang masuk ke Waduk Saguling, sehingga dapat diketahui seberapa besar potensi air total yang masuk ke waduk dari aliran sungai lokal dan informasi dari pos duga air Citarum-Nanjung.

Tujuan dari pengkajian ini adalah melakukan analisis potensi aliran lokal dengan model HEC-HMS dan potensi daya listrik yang dapat dibangkitkan dengan model HEC-Ressim. Model HEC-HMS ini menggunakan parameter hidrologi untuk menghasilkan debit sintetis dengan menggunakan data hujan sebagai inputan.

\section{METODOLOGI}

Model HEC-HMS merupakan suatu model yang dilakukan dengan membagi DAS utama menjadi beberapa sub DAS kecil. Hal ini diperlukan agar karakteristik DAS secara keseluruhan terwakili dalam model tersebut. Data masukan dari model ini adalah data hujan yang kemudian akan dikonversi menjadi data debit.

Model HEC-HMS telah banyak digunakan sebagai model hujan limpasan dengan hasil kalibrasi yang memuaskan pada berbagai studi. Syahputra (2015) menggunakan model tersebut untuk kajian hidrologi dan analisa kapasitas tampang sungai Krueng Langsa. Simulasi hidrologi dilakukan berdasarkan data curah hujan rencana periode ulang 2 tahun. Debit banjir yang didapatkan dengan menggunakan software HEC-HMS sebesar $59.30 \mathrm{~m}^{3} /$ detik. Nilai tersebut mendekati nilai debit dengan analisis passing capacity pada penampang sungai, yaitu $60,07 \mathrm{~m}^{3}$ /detik. Suprapto dkk. (2016) melakukan penelitian tentang Prediksi Pasok Dan Kebutuhan Air Sungai Ciliwung Pada Ruas Jembatan Panus Sampai Manggarai. Dalam Penelitian tersebut dilakukan prediksi pasokan air, debit hasil keluaran HEC-HMS dibandingkan dengan debit observasi. Optimasi dilakukan dengan trial and error pada parameter Loss yang terdiri initial loss, constant rate, dan impervious. Berdasarkan hasil optimasi didapatkan selisih kesalahan paling kecil 0.34\% untuk volume dan $21.9 \%$ untuk debit puncak. Namun demikian, hal ini perlu memperhatikan pada saat melakukan kalibrasi, karena akibat adanya perubahan tata guna lahan yang berpengaruh terhadap hasil simulasi. Hal ini dinyatakan oleh Nilda, Adyana, dan Merit (2015) pada penelitian di DAS Cisadane hulu yang menyatakan bahwa terdapat pengaruh akibat perubahan penggunaan lahan berbagai skenario rehabilitasi akan berpengaruh terhadap parameter hidrologi.

Pada penelitian ini menggunakan model parameter Transform dan Loses, dengan nilai parameter berupa Curve Number yang dihasilkan dari peta tata guna lahan dan Hydrologic Soil Groups. Model tersebut telah terbukti cukup baik pada berbagai penelitian (Kabiri dkk. (2013) serta Choudhari dkk. (2014).

Pembangunan model hujan limpasan ini tidak lepas dari data masukan berupa data hujan, tata guna lahan, karakteristik aliran dasar dan topografi. Selain data tersebut juga dikumpulkan data untuk keperluan kalibrasi dan verifikasi. Data tersebut berupa data debit pengamatan pada pos duga air Citarum-Nanjung dan debit total yang masuk ke Waduk Saguling yang dihasilkan dari perhitungan menggunakan persamaan sebagai berikut.

$$
\mathrm{I}-\mathrm{O}=\frac{d s}{d t}
$$

Dengan I adalah debit yang masuk $\left(\mathrm{m}^{3} / \mathrm{s}\right), 0$ adalah debit yang keluar $\left(\mathrm{m}^{3} / \mathrm{s}\right), \mathrm{dS} / \mathrm{dt}$ adalah perubahan tampungan yang terjadi $\left(\mathrm{m}^{3}\right)$. Gambar 1 adalah kerangka pikir analisis hujan limpasan dalam rangka perhitungan ketersediaan air pada Waduk Saguling. 


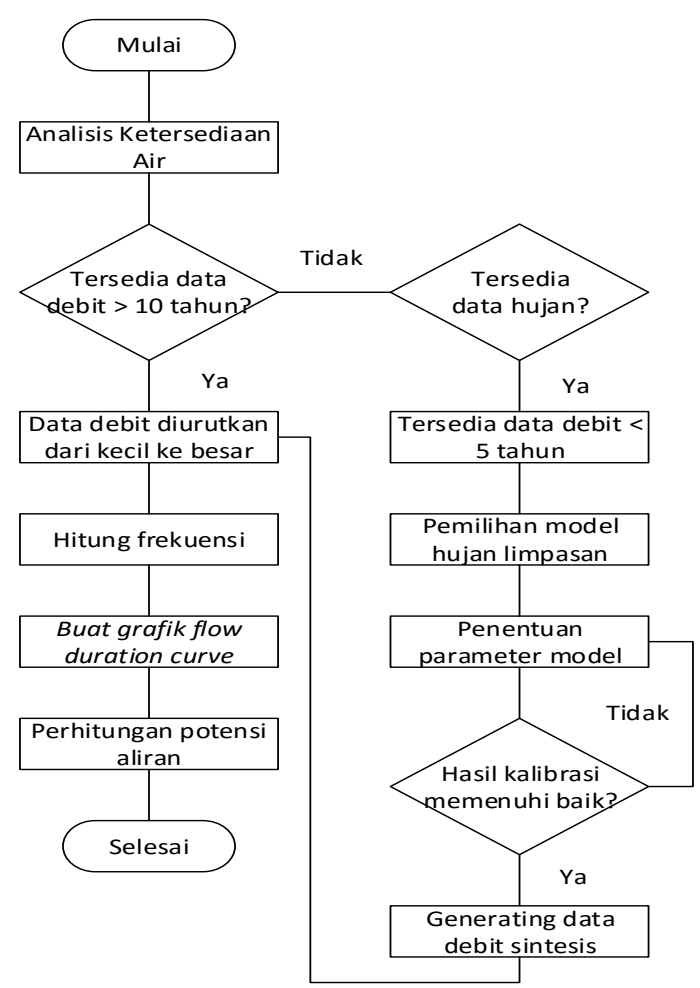

Gambar 1 Kerangka pikir perhitungan potensi air

Tahap yang dilakukan dalam kegiatan ini adalah menentukan batas DAS kajian dengan bantuan data topografi, mengetahui jumlah pos duga air dan pos hujan yang ada di dalam DAS, mendeteksi panjang data debit dan data hujan, menghitung hujan wilayah, melakukan analisa peta tata guna lahan sesuai DAS kajian, membuat skema model HEC-HMS, kalibrasi model dengan metode Trial and Error terhadap data debit, melakukan pembangkitan data debit, dan menghitung potensi air. Adapun parameter yang terkandung dalam model HEC-HMS seperti pada uraian berikut ini.

\section{Parameter Transform}

Parameter ini menghitung lamanya waktu perubahan air hujan yang turun untuk menjadi limpasan. Parameter ini secara eksplisit ditentukan oleh parameter Lag Time yang tergantung panjang, kemiringan, penampang melintang sungai dan koefisien kekasarannya. Waktu tenggang parameter ini dapat diperkirakan melalui kalibrasi untuk yang mempunyai data pengamatan di pos duga air. Pada kasus yang tidak ada datanya, disarankan waktu tenggangnya diperkirakan dari waktu konsentrasi melalui rumus:

$$
\mathrm{t}_{\text {lag }}=0.6 \mathrm{t}_{\mathrm{c}}
$$

Sedangkan waktu konsentrasi diperkirakan dari rumus :

$$
\mathrm{t}_{\mathrm{c}}=\mathrm{t}_{\text {sheet }}+\mathrm{t}_{\text {shallow }}+\mathrm{t}_{\text {channel. }}
$$

dengan $\mathrm{t}_{\text {lag }}$ adalah waktu tenggang, $\mathrm{t}_{\mathrm{c}}$ adalah waktu konsentrasi, $t_{\text {sheet }}$ adalah jumlah dari waktu perjalanan segmen aliran lapisan atau sheet di atas permukaan tanah, $\mathrm{t}_{\text {shallow }}$ adalah jumlah waktu perjalanan dari aliran dangkal (shallow) di jalanan, selokan, alur tanah, $\mathrm{t}_{\text {channel }}$ adalah jumlah waktu perjalanan dari saluran atau sungai. Untuk alur sungai dibutuhkan data penampang melintang dan perkiraan kecepatan menggunakan Manning $\mathrm{n}$.

\section{Parameter kehilangan (Losses)}

Metode losses ini mampu memperhitungkan kehilangan hujan secara kontinu terutama pada saat tidak terjadi hujan, di mana kemampuan tanah untuk menyerap air menjadi lebih besar (recovery). Metode ini dipengaruhi oleh faktor kelengasan tanah. Tabel 1 adalah tingkat kehilangan air untuk setiap jenis tanah.

Tabel 1 Loss Rates

\begin{tabular}{lc}
\hline \multicolumn{1}{c}{ Description } & $\begin{array}{c}\text { Range of Loss } \\
\text { Rates (in/hr) }\end{array}$ \\
\hline Deep sand, deep loess, aggregated silts & $0.30-0.45$ \\
\hline Shallow loess, sandy loam & $0.15-0.30$ \\
\hline $\begin{array}{l}\text { Clay loams, shallow sandy loam, soils } \\
\text { low in organic content, and soils usually } \\
\text { high in clay }\end{array}$ & $0.05-0.15$ \\
\hline $\begin{array}{l}\text { Soils that swell significantly when wet, } \\
\text { heavy plastic clays, and certain saline } \\
\text { soils }\end{array}$ & $0.00-0.05$ \\
\hline $\begin{array}{l}\text { Sumber: Technical Reference Manual HMS } 4.0 \text { (2000) } \\
\end{array}$
\end{tabular}




\section{Parameter aliran dasar (Baseflow)}

Metode ini menggunakan linier reservoir untuk mensimulasi aliran dasar setelah hujan berhenti. Infiltrasi yang dihitung sebelumnya berperan sebagai inflow bagi waduk linier. Metode ini dapat menggunakan satu atau dua lapis dengan pembagian $50 \%$ dan $50 \%$.

Parameter dalam metode ada 6, yaitu:

a) Air tanah lapis 1 ada tiga parameter, yaitu kondisi awal $\left(\mathrm{m}^{3} / \mathrm{s} / \mathrm{km}^{2}\right)$, koefisien tampungan waduk (jam), dan jumlah waduk.

b) Air tanah lapis 2 ada tiga parameter juga, yaitu kondisi awal $\left(\mathrm{m}^{3} / \mathrm{s} / \mathrm{km}^{2}\right)$, koefisien tampungan waduk (jam), dan jumlah waduk.

Kondisi awal menggambarkan kontribusi baseflow yang berasal dari lapisan air tanah pertama dan kedua. Koefisien tampungan waduk adalah waktu dari simpanan air di waduk dalam setiap lapisan, karena diperhitungkan dalam jam maka akan memberi makna tentang waktu respons dari sub-DAS.

\section{Parameter Routing}

Untuk mengkalkulasi routing, digunakan model Muskingum - Cunge Standard Section. Walaupun populer dan mudah digunakan, parameter model Muskingum tidak dapat ditentukan atau diukur secara fisik sehingga agak sulit diperkirakan. Selanjutnya persamaan didasarkan pada asumsi yang tidak sejalan dengan saluran natural, sehingga model Muskingum-Cunge, mengatasi limitasi ini. Model ini didasarkan pada persamaan kontinuitas, seperti persamaan (3) dan bentuk difusi dari persamaan momentum (persamaan 4).

$$
\frac{\partial A}{\partial t}+\frac{\partial Q}{\partial x}=q_{L}
$$

Dimana $\mathrm{q}_{\mathrm{L}}$ adalah lateral flow.

$$
S_{f}=S_{o}-\frac{\partial y}{\partial x}
$$

Mengkombinasi persamaan ini dan menggunakan pendekatan linier menghasilkan persamaan difusi konvektif (Miller dan Cunge, 1975), seperti:

$$
\frac{\partial Q}{\partial t}+c \frac{\partial Q}{\partial x}=\mu \frac{\partial^{2} Q}{\partial x^{2}}+c q_{L}
$$

Dimana c adalah kecepatan gelombang, $\mu$ adalah difusivitas hidraulik

Kecepatan gelombang dan difusivitas hidraulik dinyatakan sebagai berikut:

$$
c=\frac{d Q}{d A}
$$

dan

$$
\mu=\frac{Q}{2 B S_{o}}
$$

Dengan B adalah lebar atas permukaan air.

Perbedaan pendekatan yang terbatas dari derivatif parsial, dikombinasikan dengan persamaan Muskingum, menghasilkan:

$O_{t}=C_{1} I_{t-1}+C_{2} I_{t}+C_{3} O_{t-1}+C_{4}\left(q_{L} \Delta x\right) \cdots \cdots .(9)$

Koefisien yang digunakan:

$$
\begin{gathered}
C_{1}=\frac{\frac{\Delta t}{K}+2 X}{\frac{\Delta t}{K}+2(1-X)} \\
C_{2}=\frac{\frac{\Delta t}{K}-2 X}{\frac{\Delta t}{K}+2(1-X)} \\
C_{3}=\frac{2(1-X)-\frac{\Delta t}{K}}{\frac{\Delta t}{K}+2(1-X)} \\
C_{4}=\frac{2\left(\frac{\Delta t}{K}\right)}{\frac{\Delta t}{K}+2(1-X)}
\end{gathered}
$$

Dengan $\mathrm{X}$ adalah parameter saluran, $\mathrm{K}$ adalah koefisien manning, $\Delta \mathrm{t}$ dan $\Delta \mathrm{x}$ adalah jenjang waktu dan langkah dalam perhitungan.

Untuk parameter K dan X adalah (Cunge, 1969; Ponce dan Yevjevich, 1978, dalam Technical Reference Manual HMS 4.0):

$$
\begin{gathered}
K=\frac{\Delta x}{c} \ldots . . . \\
X=\frac{1}{2}\left(1-\frac{Q}{B S_{o} c \Delta x}\right)
\end{gathered}
$$

Parameter c, Q dan B berubah menurut waktu, sehingga koefisien $C_{1}, C_{2}, C_{3}$, dan $C_{4}$ juga harus berubah. Program mengkomputasi ulang pada setiap waktu dan langkah, $\Delta \mathrm{t}$ dan $\Delta \mathrm{x}$ menggunakan algoritma yang diusulkan oleh Ponce (1986) dalam Technical Reference Manual HMS 4.0. Dimana $\Delta \mathrm{x}$ dihitung sebagai:

$$
\Delta x=c \Delta t
$$

Nilai tersebut dibatasi sehingga:

$$
\Delta x<\frac{1}{2}\left(c \Delta t+\frac{Q_{o}}{B S_{o} c}\right)
$$

Berikut aliran $\mathrm{Q}_{0}$ (aliran referensi), dihitung dari hidrograf inflow sebagai:

$$
Q_{o}=Q_{B}+\frac{1}{2}\left(Q_{\text {peak }}-Q_{B}\right)
$$


Dengan $Q_{в}$ adalah Aliran dasar, $Q_{\text {peak }}$ adalah debit puncak inflow. Penelusuran hanya dapat dilakukan jika ada data panjang dan kemiringan sungai.

\section{Perhitungan debit andalan}

Apabila data debit tersedia dalam suatu aliran sungai maka dapat langsung dihitung debit andalannya, tetapi apabila tidak tersedia data debitnya maka harus dilakukan analisis hujan limpasan menggunakan model hidrologi. Apabila data debit telah tersedia maka perhitungan debit andalan dapat dilakukan dengan mengikuti SNI No. 6738:2015 tentang perhitungan debit andalan sungai dengan kurva durasi debit. Rumus yang digunakan dalam perhitungan debit andalan dengan metode kekerapan adalah sebagai berikut :

$$
P(X \geq \mathrm{x})=\frac{\mathrm{m}}{\mathrm{n}+1} 100 \%
$$

Dengan $\mathrm{P}(\mathrm{X}<\mathrm{x})$ adalah probabilitas terjadinya variabel $\mathrm{X}$ (debit aliran) yang lebih besar dari $\mathrm{X}$ $\mathrm{m}^{3} / \mathrm{s}, \mathrm{m}$ adalah peringkat data, $\mathrm{n}$ adalah jumlah data, $\mathrm{X}$ adalah seri data debit, $\mathrm{x}$ adalah debit andalan jika probabilitas sesuai dengan peruntukannya.

\section{Perhitungan hujan wilayah}

Perhitungan hujan wilayah menggunakan metode Polygon Thiesen. Berdasarkan peta digital yang ada, luas daerah pengaruh masing-masing pos (An) dan luas daerah aliran keseluruhan (A) dapat dihitung. Hujan rata-rata daerah aliran dapat dihitung menggunakan rumus sebagai berikut:

$$
R t=\frac{\mathrm{A}_{1} \mathrm{R}_{1}+\mathrm{A}_{2} \mathrm{R}_{2}+\ldots+\mathrm{A}_{\mathrm{n}} \mathrm{R}_{\mathrm{n}} .}{\mathrm{A}_{1}+\mathrm{A}_{2}+\ldots+\mathrm{A}_{\mathrm{n}} \mathrm{R}_{\mathrm{n}} .}
$$

Dengan Rt adalah Curah hujan daerah, $\mathrm{A}_{1,2, \mathrm{n}}$ adalah Luas polygon pos 1,2 hingga $n, R_{1,2, n}$ adalah Curah hujan pos tiap-tiap pos.

\section{HASIL DAN PEMBAHASAN}

Lokasi kajian adalah Waduk Saguling yang berada pada koordinat $6^{\circ} 54^{\prime} 45^{\prime \prime} \mathrm{LS}-107^{\circ} 21^{\prime} 58^{\prime \prime} \mathrm{BT}$, berada di Kabupaten Bandung Barat, Provinsi Jawa Barat. Gambar 2 adalah batas DAS Waduk Saguling lengkap dengan kondisi topografinya.

\section{Karakteristik hidrologi DAS Waduk Saguling}

Pos hujan di DAS Waduk Saguling ada 25 pos, dikelola PT Indonesia Power dan BPSDA Citarum dengan kondisi ketersediaan data seperti pada Tabel L-1 (terlampir) dan distribusi penyebaran pos hujan dan polygon Thiessen untuk DAS Waduk Saguling seperti pada Gambar L-1 dan L-2 (terlampir).

Jumlah pos duga air yang terdapat di kawasan DAS Waduk Saguling ada 21 pos, tetapi yang digunakan sebagai kalibrasi model hanya pos duga air Citarum-Nanjung dan pengamatan tinggi muka air di waduk Saguling. Adapun distribusi penyebaran pos duga air seperti pada Gambar L-3 (terlampir).

Ketersediaan data debit aliran pengamatan sangat diperlukan untuk analisis, apabila di setiap subDAS telah tersedia data aliran yang valid maka tidak diperlukan lagi model hujan-limpasan untuk membangkitkan data debit di setiap subDAS tersebut. Kenyataan yang ada, ketersediaan data debit aliran di anak-anak sungai sampai saat ini masih terbatas.

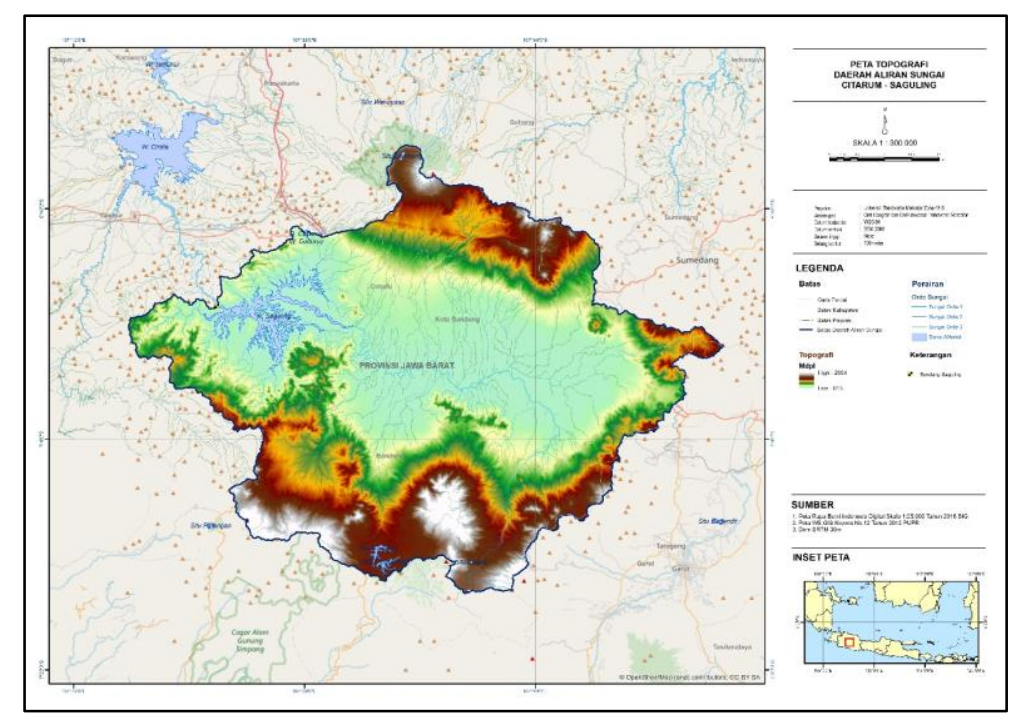

Gambar 2 Batas DAS Waduk Saguling 
Data debit existing di pos duga air CitarumNanjung tersedia pada periode tahun 1973-2017 yang diperoleh dari Buku Data Debit Sungai Nasional Tahun 2017, tetapi yang digunakan dalam penelitian ini adalah tahun 1989-2017, seperti pada Gambar 3.

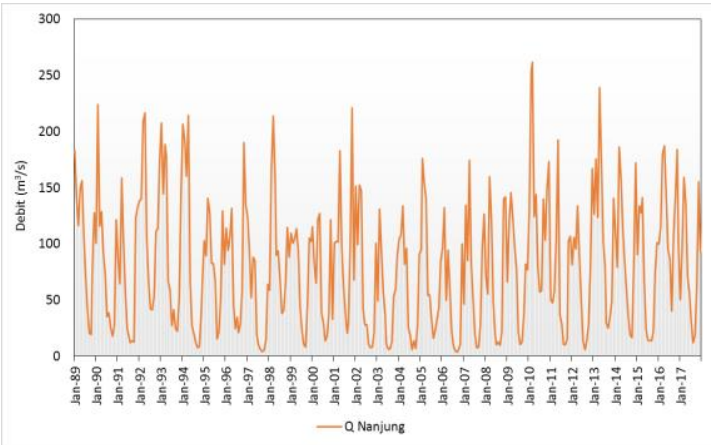

Gambar 3 Data Debit Bulanan Citarum-Nanjung

\section{Karakteristik topografi}

Berdasarkan analisis peta dan perangkat lunak Sistem Informasi Geografis (SIG) didapatkan bahwa karaketristik topografinya DAS Waduk Saguling adalah sebagai berikut:

a) Luas DAS Waduk Saguling berdasarkan peta DEM dan peta sungai digital dengan menggunakan perangkat lunak SIG adalah 2.283 $\mathrm{km}^{2}$. Ketinggian lahan di DAS tersebut berkisar antara $613 \mathrm{~m}$ DPL - $2.604 \mathrm{~m}$ DPL.

b) Dari segi tutupan lahan, DAS Waduk Saguling didominasi oleh persawahan sebesar 26,04\% seperti terlihat pada Gambar 4. Penggunaan lahan di DAS Waduk Saguling meliputi persawahan sebesar 26,04\%, kawasan terbangun sebesar $22,81 \%$, hutan primer sebesar 11,66 \% dan sisanya merupakan hutan sekunder, kebun campuran, ladang, perkebunan dan semak belukar. Tabel 2 adalah kondisi tata guna lahan di DAS Waduk Saguling.

Tabel 2 Tata Guna Lahan di DAS Waduk Saguling

\begin{tabular}{c|l|c|c}
\hline No & \multicolumn{1}{|c|}{ Penggunaan Lahan } & Luas $\mathbf{( k m}^{\mathbf{}} \mathbf{)}$ & Prosentase (\%) \\
\hline 1 & Hutan Primer & 269 & 11,7 \\
\hline 2 & Hutan Sekunder & 32,4 & 1,41 \\
\hline 3 & Kebun Campuran & 226 & 9,81 \\
\hline 4 & Ladang/Tegalan & 342 & 14,8 \\
\hline 5 & Perkebunan & 120 & 5,20 \\
\hline 6 & Sawah & 601 & 26,0 \\
\hline 7 & Semak/Belukar & 152 & 6,58 \\
\hline 8 & Sungai/Danau/Waduk/Situ & 39,1 & 1,69 \\
\hline 9 & Terbangun & 526 & 22,8 \\
\hline \multicolumn{2}{l|}{ Sumber: Analisa dari Peta Tata Guna Lahan, BPN tahun 2012 }
\end{tabular}

c) Bila ditinjau dari segi jenis tanah (Gambar 5), DAS Waduk Saguling didominasi oleh jenis andesit dan basalt sebesar $60.15 \%$. Jenis tanah tersebut berupa bongkahan sehingga lebih besar potensinya dalam meloloskan air hujan menjadi aliran ke dalam permukaan tanah. Dengan tersedianya data tata guna lahan dan jenis tanah maka dapat dihasilkan nilai HSG (Gambar 6) yang dapat mendukung parameter loss dan transform.

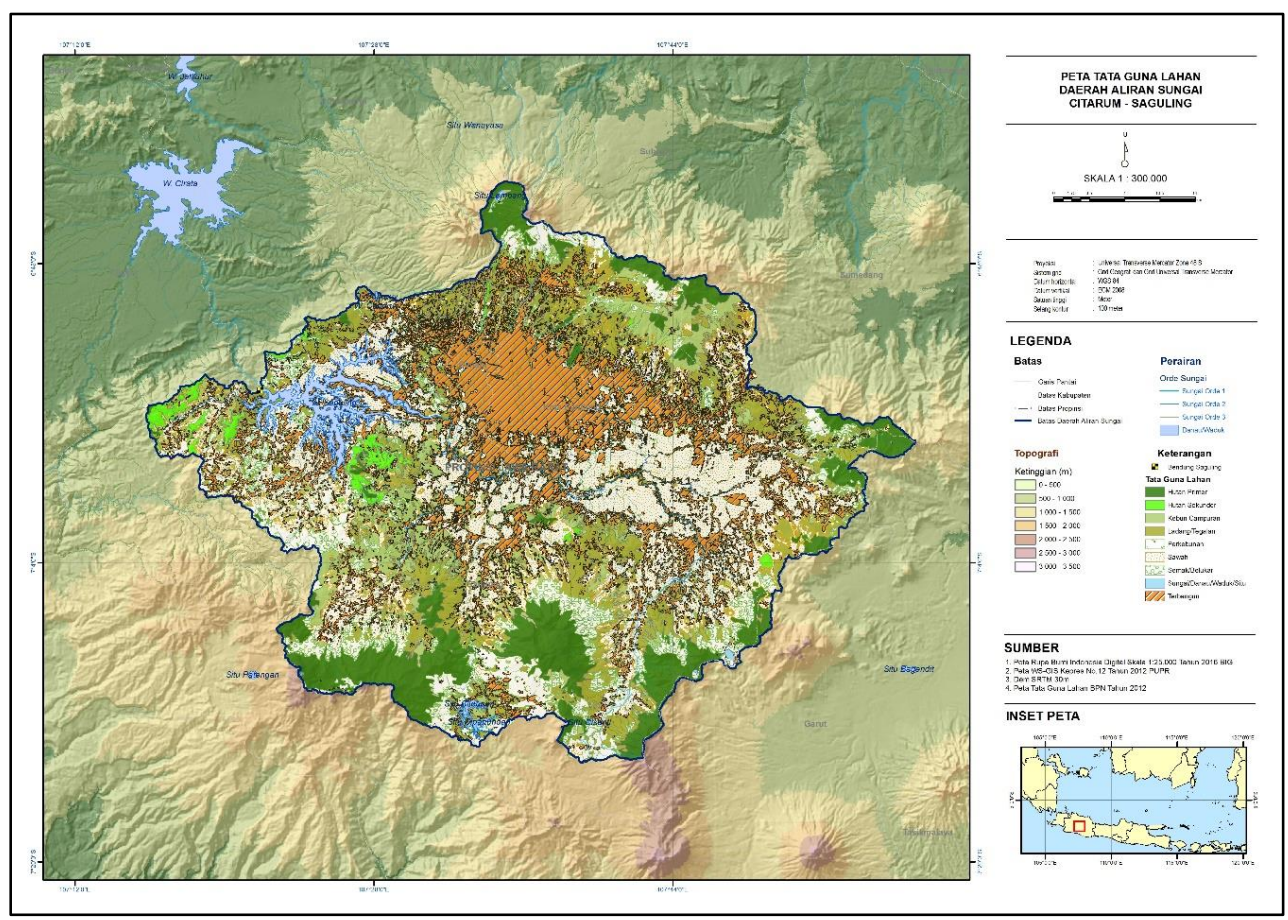

Gambar 4 Peta Tata Guna Lahan DAS Waduk Saguling

Sumber: Peta tata guna lahan BPN tahun 2012 dan hasil analisis 


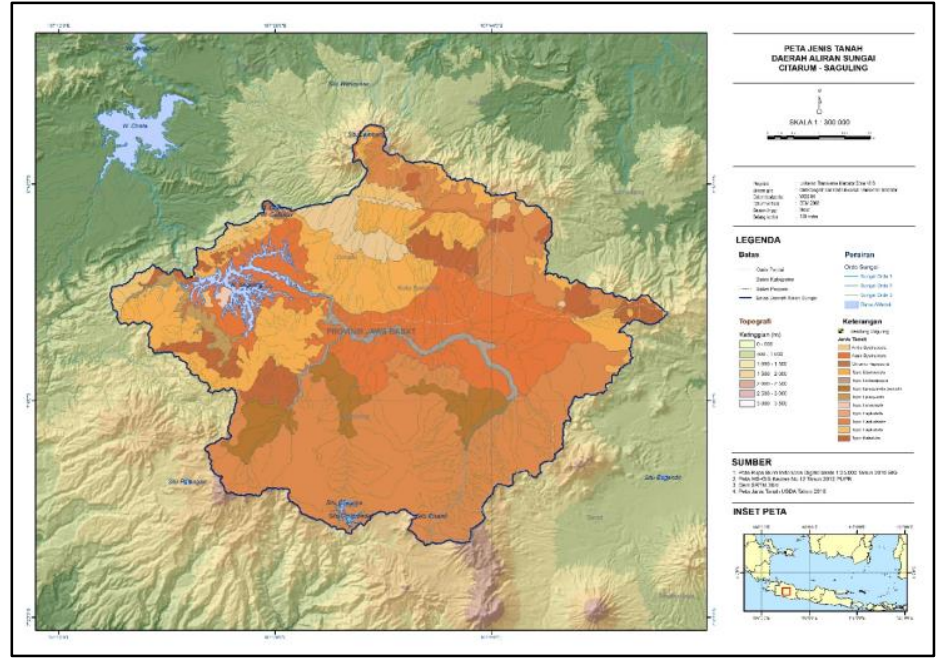

Gambar 5 Peta Jenis Tanah di DAS Waduk Saguling

Sumber: Peta jenis tanah USDA tahun 2010 dan hasil analisis

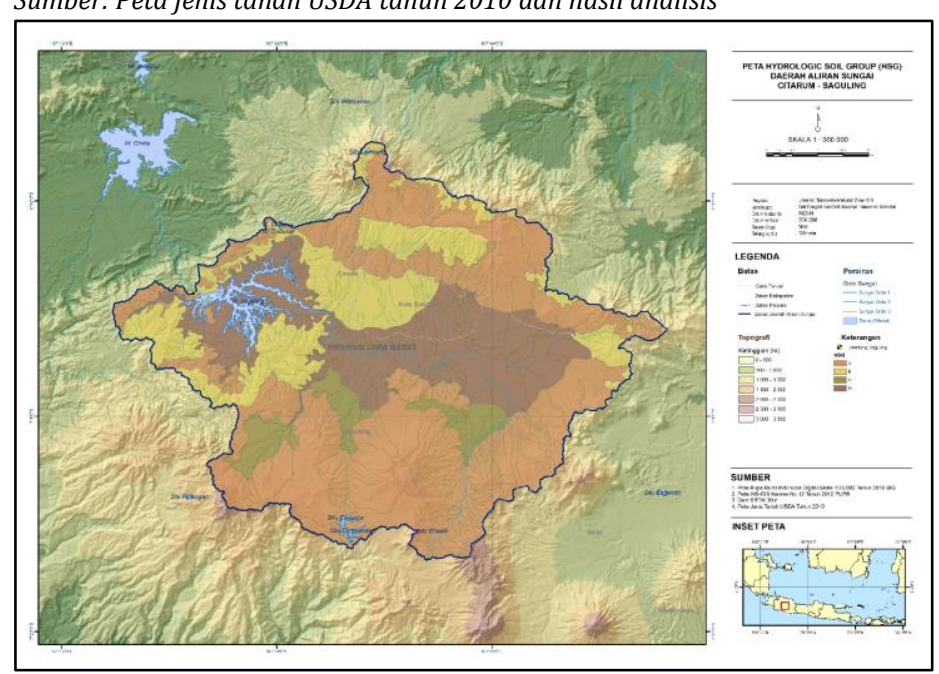

Gambar 6 Peta Hydrologic Soil Group di DAS Waduk Saguling

Sumber: hasil analisis

\section{Pemodelan Hujan Limpasan}

Model yang digunakan dalam analisis lokal inflow ini adalah dengan software Hydrologic Engineering Center-Hydrologic Modeling System (HEC-HMS). Model ini membagi DAS ke dalam subDAS kecil. Berdasarkan analisa GIS, DAS studi dibagi menjadi 55 sub DAS kecil dengan skema seperti ditampilkan pada Gambar 7. Parameter yang dikalibrasi dalam model ini adalah:

a) parameter deficit constant yang menggambarkan besaran air yang lolos untuk menjadi infiltrasi.

b) parameter transform yang menggambarkan waktu yang dibutuhkan air hujan yang jatuh ke permukaan tanah untuk menjadi aliran permukaan.

c) parameter baseflow yang menggambarkan karakteristik aliran dasar sungai.

Tabel 3 dan 4 adalah parameter hidrologi yang digunakan dalam model. Perhitungan kalibrasi yang dilakukan menggunakan parameter di atas untuk mencari kesalahan absolut (error) terkecil sehingga debit hasil perhitungan mendekati debit pengamatan. Kalibrasi dilakukan di Waduk Saguling dan pos duga air Citarum-Nanjung. Gambar 8 dan Gambar 9 menunjukkan hasil kalibrasi untuk kedua lokasi tersebut. 


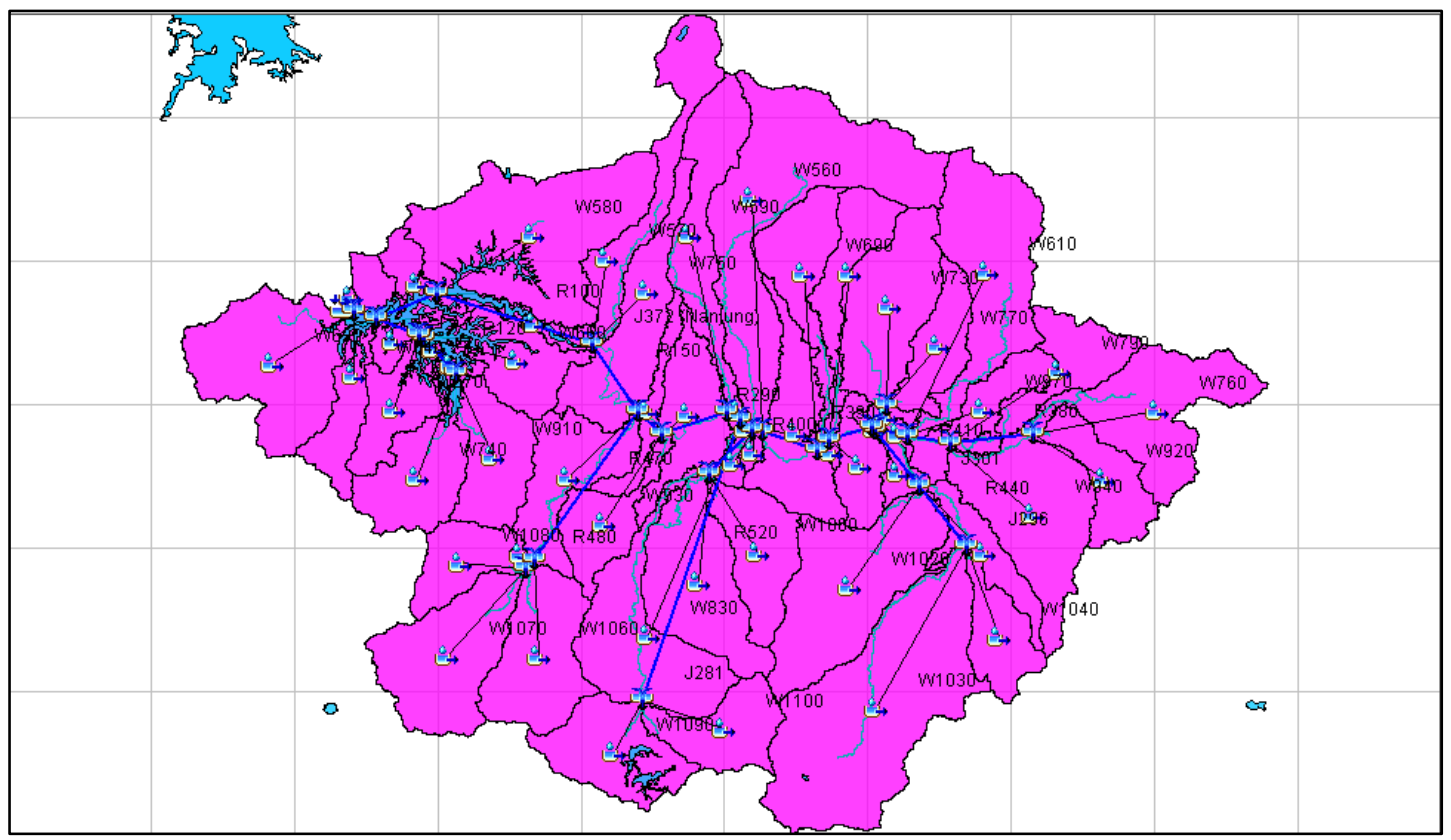

Gambar 7 Skema Model Hujan - Aliran DAS Waduk Saguling dengan menggunakan HEC-HMS.

Tabel 3 Parameter Deficit Constant untuk DAS Waduk Saguling

\begin{tabular}{|c|c|c|c|c|c|}
\hline SubDAS & Maximum Storage $(\mathrm{mm})$ & Constant Rate $(\mathrm{mm} / \mathrm{hr})$ & SubDAS & Maximum Storage $(\mathrm{mm})$ & Constant Rate $(\mathrm{mm} / \mathrm{hr})$ \\
\hline W1000 & 150,29 & 10 & W730 & 97,41 & 10 \\
\hline W1010 & 99,38 & 10 & W740 & 93,59 & 10 \\
\hline W1020 & 108,44 & 10 & W750 & 80,83 & 10 \\
\hline W1030 & 204,51 & 10 & W760 & 150,90 & 10 \\
\hline W1040 & 166,06 & 10 & W770 & 94,43 & 10 \\
\hline W1050 & 142,26 & 10 & W780 & 55,28 & 10 \\
\hline W1060 & 272,11 & 10 & W790 & 94,33 & 10 \\
\hline W1070 & 189,91 & 10 & W800 & 36,00 & 10 \\
\hline W1080 & 115,16 & 10 & W810 & 84,30 & 10 \\
\hline W1090 & 218,49 & 10 & W820 & 57,34 & 10 \\
\hline W1100 & 205,07 & 10 & W830 & 190,47 & 10 \\
\hline W560 & 117,76 & 10 & W840 & 38,23 & 10 \\
\hline W570 & 167,34 & 10 & W850 & 53,79 & 10 \\
\hline W580 & 79,07 & 10 & W860 & 30,80 & 10 \\
\hline W590 & 116,34 & 10 & W870 & 65,94 & 10 \\
\hline W600 & 60,03 & 10 & W880 & 94,14 & 10 \\
\hline W610 & 140,89 & 10 & W890 & 58,14 & 10 \\
\hline W620 & 63,06 & 10 & W900 & 58,92 & 10 \\
\hline W630 & 107,89 & 10 & W910 & 107,14 & 10 \\
\hline W640 & 81,05 & 10 & W920 & 145,27 & 10 \\
\hline W650 & 44,43 & 10 & W930 & 99,32 & 10 \\
\hline W660 & 61,73 & 10 & W940 & 112,06 & 10 \\
\hline W670 & 67,63 & 10 & W950 & 55,22 & 10 \\
\hline W680 & 30,59 & 10 & W960 & 52,55 & 10 \\
\hline W690 & 98,05 & 10 & W970 & 60,72 & 10 \\
\hline W700 & 27,45 & 10 & W980 & 70,17 & 10 \\
\hline W710 & 33,73 & 10 & W990 & 166,95 & 10 \\
\hline W720 & 81,71 & 10 & & & \\
\hline
\end{tabular}

Tabel 3 dihasilkan berdasarkan analisis peta HSG seperti pada Gambar 6. Berdasarkan Gambar 6 terlihat bahwa wilayah kajian terdiri dari empat kelompok tanah yaitu A, B, C dan D. Tetapi kelompok tanah yang tersebar merata pada DAS Saguling adalah kelompok tanah tipe A. Nilai interval constant rate untuk golongan tanah tipe A berkisar 7,62 - 11,43 mm/hr. Walaupun pada beberapa sisi wilayah DAS Saguling memiliki kategori tanah tipe $\mathrm{B}, \mathrm{C}$ dan $\mathrm{D}$, tetapi pada saat proses kalibrasi, nilai tersebut tidak terlalu berpengaruh signifikan terhadap perubahan debit 
yang terjadi. Hasil kalibrasi menghasilkan nilai terbaik untuk parameter HSG adalah 10.

Selain, parameter constant rate, parameter yang dikalibrasi adalah parameter linear reservoir. Berdasarkan hasil kalibrasi yang dilakukan, dihasilkan parameter linear reservoir sebagai berikut: a) GW 1 Initial sebesar $0,08 \mathrm{~m}^{3} / \mathrm{s} / \mathrm{km}^{2}$

b) GW 1 coefficient sebesar $50 \mathrm{hr}$

c) GW 2 Initial sebesar $0,005 \mathrm{~m}^{3} / \mathrm{s} / \mathrm{km}^{2}$

d) GW 2 coefficient $60 \mathrm{hr}$

Tabel 4 Input Parameter Transform untuk DAS Waduk Saguling

\begin{tabular}{|c|c|c|c|}
\hline SubDAS & Lag Time (min) & SubDAS & Lag Time (min) \\
\hline W1000 & 191,24 & W730 & 194,58 \\
\hline W1010 & 228,96 & W740 & 114,91 \\
\hline W1020 & 226,91 & W750 & 217,52 \\
\hline W1030 & 368,37 & W760 & 243,60 \\
\hline W1040 & 161,07 & W770 & 181,78 \\
\hline W1050 & 38,10 & W780 & 118,02 \\
\hline W1060 & 241,93 & W790 & 218,19 \\
\hline W1070 & 233,44 & W800 & 40,05 \\
\hline W1080 & 124,08 & W810 & 143,70 \\
\hline W1090 & 342,81 & W820 & 190,85 \\
\hline W1100 & 206,83 & W830 & 354,74 \\
\hline W560 & 310,66 & W840 & 35,66 \\
\hline W570 & 356,21 & W850 & 114,18 \\
\hline W580 & 198,26 & W860 & 12,51 \\
\hline W590 & 340,26 & W870 & 132,42 \\
\hline W600 & 83,14 & W880 & 83,83 \\
\hline W610 & 307,32 & W890 & 52,58 \\
\hline W620 & 19,29 & W900 & 185,27 \\
\hline W630 & 144,37 & W910 & 121,01 \\
\hline W640 & 132,34 & W920 & 188,15 \\
\hline W650 & 52,02 & W930 & 160,21 \\
\hline W660 & 96,89 & W940 & 242,69 \\
\hline W670 & 121,88 & W950 & 67,40 \\
\hline W680 & 41,32 & W960 & 175,84 \\
\hline W690 & 238,88 & W970 & 176,57 \\
\hline W700 & 55,67 & W980 & 176,89 \\
\hline W710 & 93,63 & W990 & 314,98 \\
\hline W720 & 167,97 & & \\
\hline
\end{tabular}

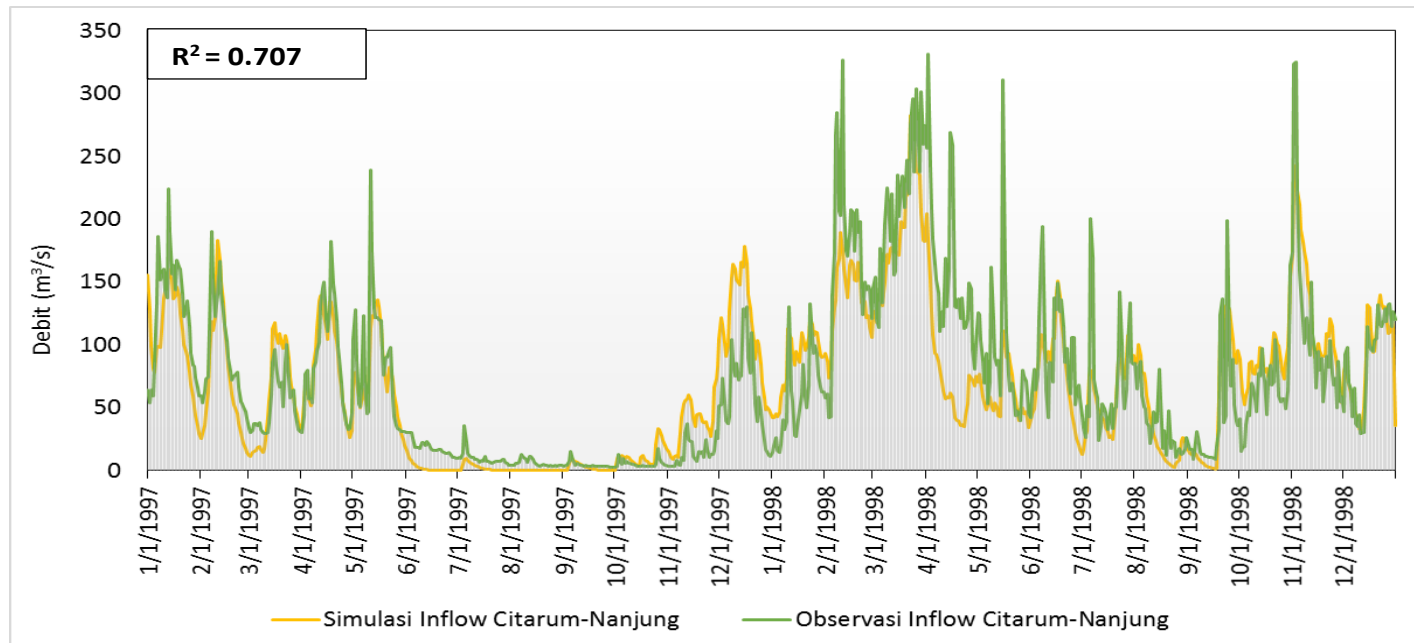

Gambar 8 Hasil kalibrasi parameter untuk pos duga air Citarum-Nanjung 


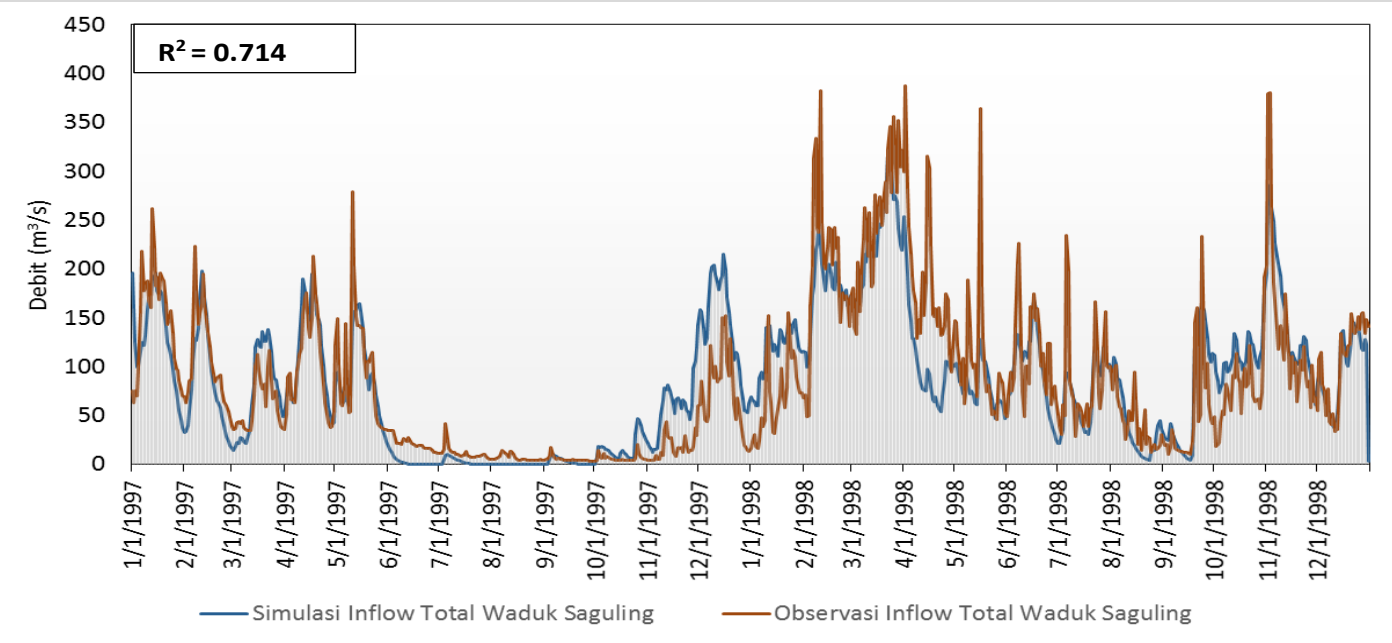

Gambar 9 Hasil kalibrasi parameter untuk Bendungan Saguling

Dengan melihat nilai $\mathrm{R}^{2}$ yang dihasilkan di pos duga air Citarum-Nanjung sebesar 0,707 dan pengamatan di Waduk Saguling sebesar 0,714 maka dapat dikatakan kalibrasi yang dilakukan untuk melihat perbedaan antara debit pengamatan dengan simulasi sudah baik. Cara lain yang dilakukan untuk melihat tingkat kehandalan model hidrologi adalah dengan cara menghitung NashSutcliffe model efficiency coefficient biasa disingkat NSE.

$$
N S E=1-\frac{\sum_{t=1}^{T}\left(Q_{m}^{t}-Q_{o}^{t}\right)^{2}}{\sum_{t=1}^{T}\left(Q_{o}^{t}-\overline{Q_{o}}\right)^{2}}
$$

Dengan $Q_{o}$ adalah debit pengamatan, $\overline{Q_{0}}$ adalah debit pengamatan rata-rata dan $Q_{m}$ adalah debit model., $Q_{0}{ }^{t}$ adalah debit pengamatan terhadap waktu $t$.

Tabel 5 Rentang Nilai NSE untuk Tingkat Kehandalan Model Hidrologi

\begin{tabular}{l|c|}
\hline \multicolumn{1}{c|}{ Goodness of fit } & NSE \\
\hline Very Good & NSE $>0,6$ \\
\hline Goodness of fit & $0,40<$ NSE $\leq 0,60$ \\
\hline Satisfactory & $0,20<$ NSE $\leq 0,40$ \\
\hline Unsatisfactory & NSE $<0,20$ \\
\hline
\end{tabular}

Sumber: Pérez-Sánchez et al. (2017)

Terlihat bahwa dengan nilai NSE yang semakin mendekati nilai 1 ( Tabel 5), artinya model yang dibentuk akurat dan handal untuk memprediksi. Kalibrasi di pos duga air Citarum-Nanjung menghasilkan nilai NSE sebesar 0,707 sedangkan kalibrasi yang dilakukan di Waduk Saguling menghasilkan nilai NSE sebesar 0,723. Selanjutnya parameter yang dihasilkan dapat digunakan untuk membangitkan (generating) data di lokasi kegiatan.

Selain melakukan tahap kalibrasi juga dilakukan tahap verifikasi dengan menganalisis hubungan debit pengamatan dengan debit simulasi di tahun yang berbeda. Tahun yang digunakan untuk melakukan verifikasi adalah tahun 20072014, hal tersebut dilihat dari ketersediaan data untuk seluruh pos hujan Tabel L-1 (terlampir). Berikut adalah hasil verifikasi di Waduk Saguling dan pos duga air Citarum-Nanjung.

Berdasarkan Gambar 10 dan Gambar 11 menunjukkan bahwa verifikasi hasil model menunjukkan nilai korelasi yang baik di titik kalibrasi pos duga air Citarum-Nanjung dengan nilai NSE sebesar 0,788 dan $\mathrm{R}^{2}$ sebesar 0,83 sedangkan verifikasi yang dilakukan di Waduk Saguling menghasilkan nilai NSE sebesar 0,8343 dan $R^{2}$ sebesar 0,83, dengan kata lain model yang dibuat andal untuk digunakan prakiraan data debit.

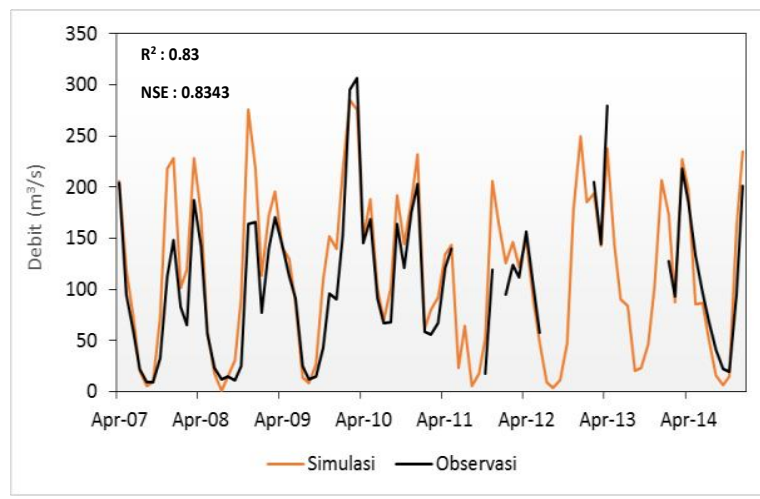

Gambar 10 Hasil verifikasi pembangkitan data debit bulanan untuk lokasi Waduk Saguling 


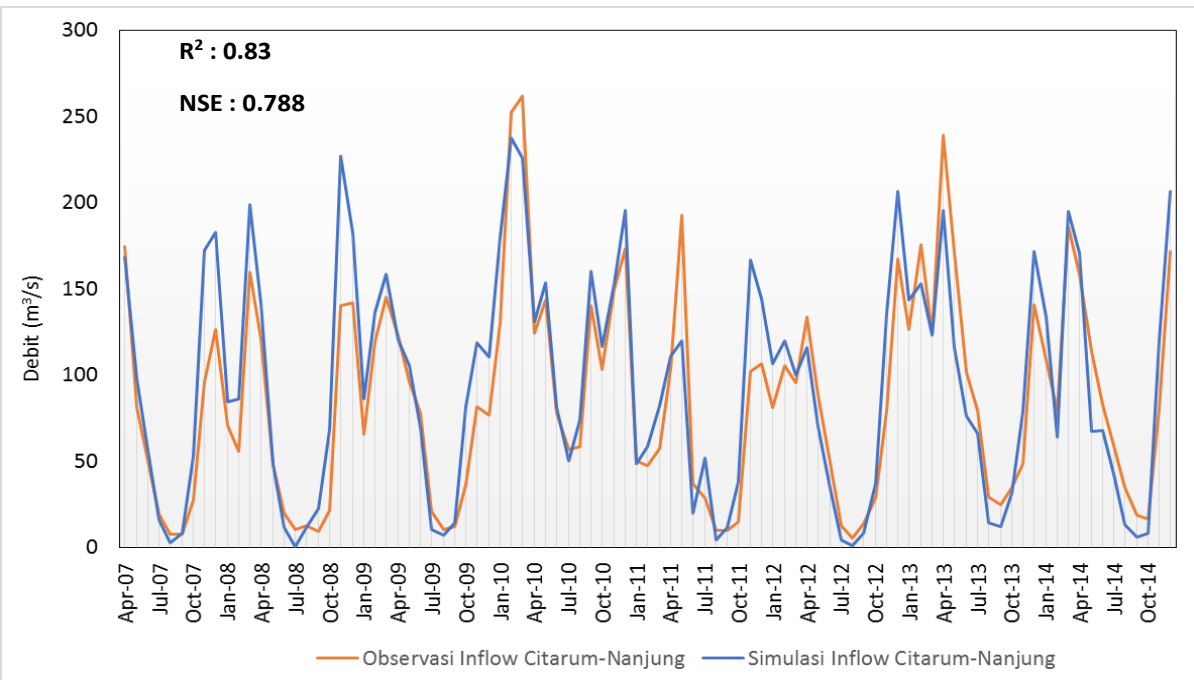

Gambar 11 Hasil verifikasi pembangkitan data debit bulanan untuk lokasi Citarum-Nanjung

Tabel 6 Debit $80 \%$ rata bulanan

\begin{tabular}{c|c|c|c|c|c|c|c|c|c|c|c|c|c|c|c|c|c|c|c|c|c|c|c|c|c|c|}
\hline \multirow{2}{*}{ Tahun } & \multicolumn{2}{|c|}{ Jan } & \multicolumn{2}{|c|}{ Feb } & \multicolumn{2}{c|}{ Mar } & \multicolumn{2}{c|}{ Apr } & \multicolumn{2}{c|}{ Mei } & \multicolumn{2}{c|}{ Jun } & \multicolumn{2}{c|}{ Jul } & \multicolumn{2}{c|}{ Agust } & \multicolumn{2}{c|}{ Sep } & \multicolumn{2}{c|}{ Okt } & \multicolumn{2}{c|}{ Nov } & \multicolumn{2}{c|}{ Des } \\
\cline { 2 - 6 } & Obs & Sim & Obs & Sim & Obs & Sim & Obs & Sim & Obs & Sim & Obs & Sim & Obs & Sim & Obs & Sim & Obs & Sim & Obs & Sim & Obs & Sim & Obs & Sim \\
\hline 2007 & 54.1 & 100.3 & 157.1 & 250.9 & 99.8 & 146.2 & 203.9 & 205.7 & 95.1 & 119.1 & 58.7 & 72.8 & 22.5 & 20.1 & 9.1 & 5.7 & 9.3 & 9.4 & 32.5 & 72.6 & 112.8 & 218.1 & 147.9 & 228.6 \\
\hline 2008 & 82.5 & 101.1 & 65.2 & 119.1 & 187.0 & 228.5 & 141.7 & 172.8 & 56.4 & 58.7 & 23.6 & 17.8 & 12.3 & 0.9 & 15.1 & 15.2 & 11.2 & 30.6 & 25.4 & 92.3 & 164.0 & 275.3 & 166.0 & 218.2 \\
\hline 2009 & 77.2 & 113.2 & 139.3 & 172.7 & 170.3 & 195.5 & 143.4 & 141.3 & 112.8 & 129.0 & 91.1 & 85.2 & 24.9 & 14.2 & 12.4 & 7.9 & 14.5 & 26.9 & 42.8 & 108.5 & 95.7 & 151.8 & 90.1 & 139.5 \\
\hline 2010 & 152.5 & 216.1 & 295.6 & 285.3 & 306.4 & 276.1 & 145.4 & 150.3 & 168.3 & 187.7 & 91.2 & 100.5 & 66.9 & 69.4 & 68.3 & 101.3 & 163.9 & 191.4 & 120.8 & 144.2 & 174.9 & 186.2 & 202.7 & 232.3 \\
\hline 2011 & 58.7 & 61.6 & 55.6 & 79.7 & 67.3 & 91.9 & 121.5 & 134.3 & 139.8 & 143.6 & & 23.0 & & 64.1 & & 5.6 & & 17.6 & 17.8 & 52.4 & 119.5 & 205.7 & & 164.7 \\
\hline 2012 & 95.2 & 125.7 & 123.8 & 146.3 & 111.6 & 122.2 & 156.5 & 149.2 & 103.2 & 89.5 & 57.7 & 48.8 & & 9.0 & & 3.4 & & 10.8 & & 47.5 & & 176.9 & & 249.3 \\
\hline 2013 & & 185.2 & 205.3 & 193.6 & 144.7 & 142.8 & 279.9 & 237.0 & & 143.6 & 119.0 & 90.6 & & 83.5 & & 20.7 & & 22.9 & & 46.3 & & 102.7 & & 207.1 \\
\hline 2014 & 127.2 & 173.0 & 92.8 & 87.4 & 217.7 & 226.8 & 185.5 & 197.0 & 133.1 & 86.0 & 97.1 & 87.0 & 69.0 & 51.5 & 40.9 & 16.1 & 22.4 & 6.4 & 19.2 & 15.1 & 94.3 & 159.3 & 201.2 & 234.5 \\
\hline ata-Rata & 92.5 & 134.5 & 141.8 & 166.9 & 163.1 & 178.8 & 172.2 & 173.4 & 115.5 & 119.7 & 76.9 & 65.7 & 39.1 & 39.1 & 29.2 & 22.0 & 44.3 & 39.5 & 43.1 & 72.4 & 126.9 & 184.5 & 161.6 & 209.3 \\
\hline $\mathrm{Q}_{80}$ & 56.9 & 92.6 & 63.3 & 85.9 & 93.3 & 116 & 138 & 140 & 79.6 & 80.5 & 44.1 & 21.9 & 14 & 7.3 & 9.8 & 5.12 & 9.7 & 8.78 & 18.3 & 40.1 & 94.9 & 142 & 102 & 160 \\
\hline
\end{tabular}

Keterangan: kolom yang kosong berarti data observasi tidak ada

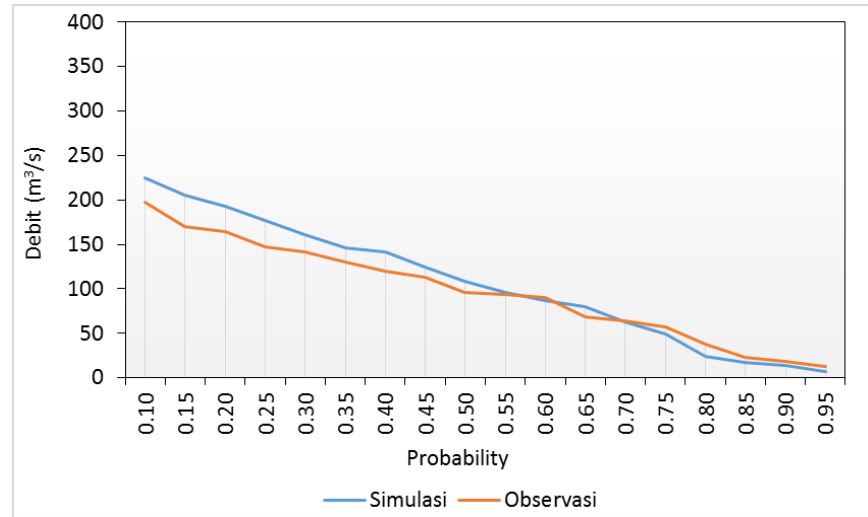

Gambar 12 Kurva durasi hasil debit simulasi dengan debit pengamatan tahun 2007-2014 di Waduk Saguling

Dari hasil pembangkitan data debit yang dilakukan juga dapat dibandingkan dengan bentuk kurva durasi dari debit pengamatan. Kurva durasi hasil debit simulasi dengan debit pengamatan dapat dilihat pada Tabel 6 dan Gambar 12 Berdasarkan Tabel 6 dan Gambar 14, terlihat verifikasi hasil simulasi tidak terlalu baik pada debit-debit tertinggi tetapi pada debit rendah digambarkan baik oleh model. Pada debit tinggi tidak terlalu baik dikarenakan banyak hal yang mempengaruhi, salah satunya adalah sumber data observasi itu sendiri. Data observasi dihasilkan dari 1,3 dari besaran debit nanjung, bukan dari lengkung debit. Sedangkan lengkung debit pada pos duga air Citarum-Nanjung pun, masih sulit untuk dikategorikan baik karena penampang pada pos duga air tersebut sangat dipengaruhi oleh penggerusan dan pengendapan yang tinggi. 
Setelah diketahui besaran nilai simulasi untuk data inflow di Citarum-Nanjung dan di Waduk Saguling, maka dapat diketahui besaran inflow sungai lokal yang masuk ke Waduk Saguling. Gambar 13 adalah kondisi debit hasil simulasi di Citarum-Nanjung, sungai lokal dan Waduk Saguling.

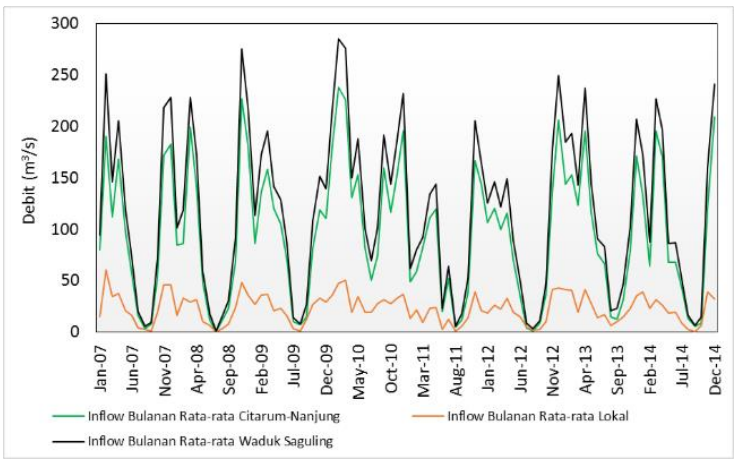

Gambar 13 Nilai simulasi di Citarum-Nanjung, Sungai Lokal dan Waduk Saguling

Sedangkan Gambar 14 dan Error! Not a valid bookmark self-reference. adalah kondisi debit andalan rata-rata bulanan dari sungai- sungai lokal. Apabila diprosentasekan maka besaran sumbangan debit air yang masuk dari sungai lokal terhadap debit air masuk total ke Waduk Saguling sebesar $21,64 \%$.

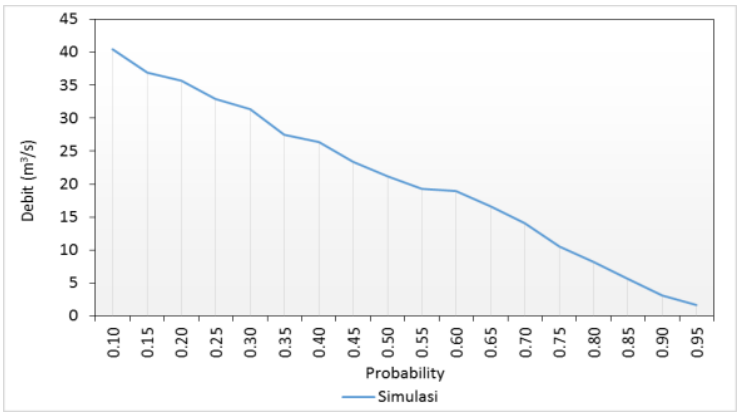

Gambar 14 Kurva durasi debit rata-rata bulanan Anak Sungai Lokal Tahun 2007-2014 Simulasi Waduk Saguling untuk Mengetahui
Besaran Listrik yang dapat dibangkitkan

Berdasarkan data debit sintetis sungai-sungai lokal tahun 2007-2014 tersebut kemudian dihitung besaran listrik rata-rata yang dapat dibangkitkan dengan perangkat lunak Hydrologic Engineering Center-Reservoir System Simulation (HEC-Ressim) menggunakan skema seperti pada Error! Reference source not found..

Analisis simulasi pembangkitan daya listrik dari sungai - sungai local yang dilakukan dengan asumsi pola operasi yang digunakan adalah pola operasi tahun 2018, maka hasil simulasi seperti ditunjukkan pada Tabel 8. Nilai debit andalan ratarata bulanan sungai lokal untuk keperluan pembangkit listrik pada Q80 $_{80}$ dan Q85 $_{\text {adalah sebesar }}$ $8,23 \mathrm{~m}^{3} / \mathrm{s}$ dan $5,69 \mathrm{~m}^{3} / \mathrm{s}$. Sehingga apabila dihitung dengan model HEC-Ressim pada skema Gambar 15, maka dihasilkan rata-rata daya listrik yang dapat dibangkitkan dari sungai lokal Waduk Saguling tersebut adalah 3,89-162,93 MW.

Tabel 7 Debit andalan rata-rata bulanan anak Sungai Lokal

\begin{tabular}{c|c}
\hline Prob & Simulasi \\
\hline 0,10 & $\mathbf{4 0 , 4 2}$ \\
\hline 0,20 & $\mathbf{3 5 , 7 4}$ \\
\hline 0,30 & $\mathbf{3 1 , 3 6}$ \\
\hline 0,40 & $\mathbf{2 6 , 3 4}$ \\
\hline 0,50 & $\mathbf{2 1 , 2 1}$ \\
\hline 0,60 & $\mathbf{1 8 , 9 5}$ \\
\hline 0,70 & $\mathbf{1 4 , 1 2}$ \\
\hline 0,80 & $\mathbf{8 , 2 3}$ \\
\hline 0,85 & $\mathbf{5 , 6 9}$ \\
\hline 0,90 & $\mathbf{3 , 0 8}$ \\
\hline 0,95 & $\mathbf{1 , 7 2}$ \\
\hline
\end{tabular}

Tabel 8 Pembangkitan daya listrik dari sungai lokal Waduk Saguling

\begin{tabular}{c|c}
\hline Bulan & Listrik (MW) \\
\hline Januari & $\mathbf{1 4 0 , 4 3}$ \\
\hline Februari & $\mathbf{3 , 8 9}$ \\
\hline Maret & $\mathbf{1 0 , 4 8}$ \\
\hline April & $\mathbf{9 , 9 6}$ \\
\hline Mei & $\mathbf{2 7 , 6 3}$ \\
\hline Juni & $\mathbf{8 2 , 7 1}$ \\
\hline Juli & $\mathbf{1 6 2 , 9 3}$ \\
\hline Agustus & $\mathbf{8 0 , 2 2}$ \\
\hline September & $\mathbf{4 5 , 7 6}$ \\
\hline Oktober & $\mathbf{8 6 , 1 6}$ \\
\hline November & $\mathbf{9 2 , 6 3}$ \\
\hline Desember & $\mathbf{6 3 , 6 0}$ \\
\hline
\end{tabular}




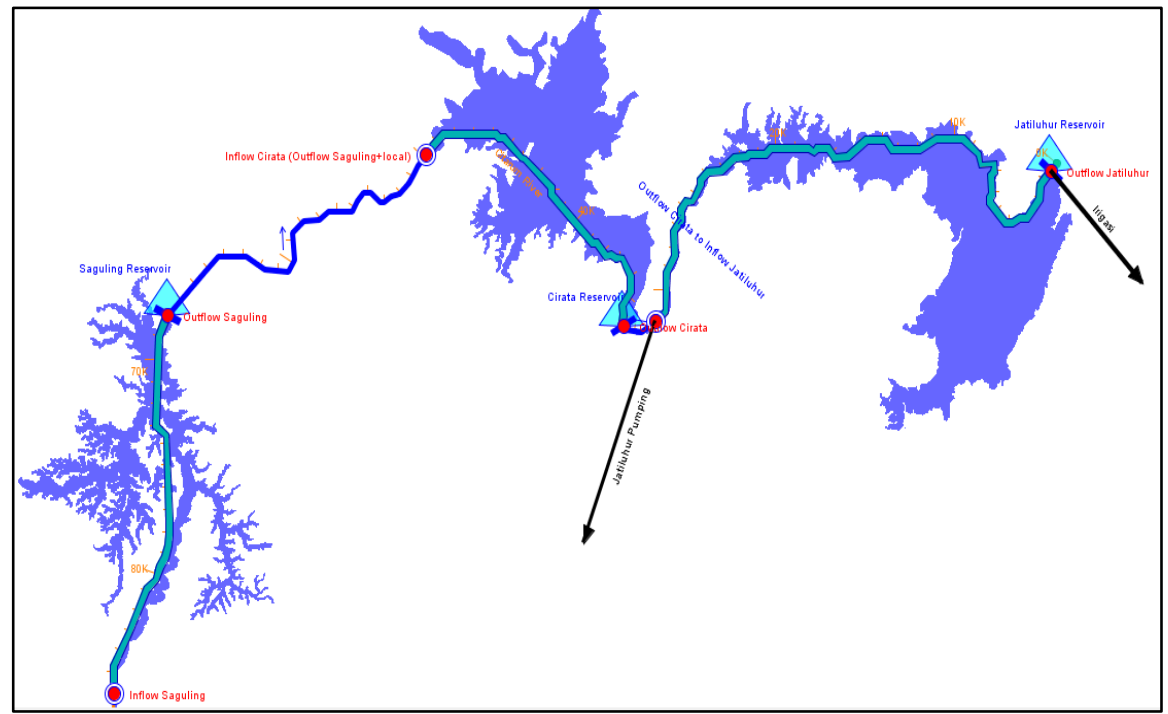

Gambar 15 Skema Simulasi Waduk Saguling

\section{KESIMPULAN}

Berdasarkan hasil penelitian yang telah dilakukan dapat disimpulkan bahwa hasil verifikasi menggunakan data hujan groundstation menunjukkan nilai $\mathrm{R}^{2}$ yang sangat baik di titik pos duga air Citarum-Nanjung dengan nilai NSE sebesar 0,788 dan $\mathrm{R}^{2}$ sebesar 0,83, sedangkan verifikasi yang dilakukan di Waduk Saguling menghasilkan nilai NSE sebesar 0,8343 dan $\mathrm{R}^{2}$ sebesar 0,83 . Hal ini menunjukkan bahwa model hujan limpasan yang dibentuk sangat baik.

Hasil simulasi menunjukkan bahwa potensi debit air dari sungai lokal menyumbangkan $21,64 \%$ dari total debit air yang masuk ke Waduk Saguling atau sebesar 16,1 - 32,9 juta $\mathrm{m}^{3}$ /tahun dengan total keseluruhan debit pada Waduk Saguling sebesar 90,2 - 185 juta $\mathrm{m}^{3}$ /tahun. Nilai debit andalan rata-rata bulanan sungai lokal untuk keperluan pembangkit listrik yaitu $\mathrm{Q}_{80}$ dan $\mathrm{Q}_{85}$ adalah sebesar $8,23 \mathrm{~m}^{3} / \mathrm{s}$ dan $5,69 \mathrm{~m}^{3} / \mathrm{s}$. Rata-rata daya listrik yang dapat dibangkitkan dari sungai lokal Waduk Saguling sebesar 3,89 - 162,93 MW.

Kelemahan dari model hujan limpasan menggunakan HEC HMS sangat bergantung pada sebaran pos hujan ground, kualitas dan kontinuitas data hujan ground di sekitar DAS. Hal ini berdampak pada jumlah tahun data yang akan disimulasikan menjadi terbatas, sesuai dengan ketersediaan data hujan tersebut.

\section{DAFTAR PUSTAKA}

Badan Standar Nasional. (2015). SNI 6738:2015 tentang Perhitungan debit andalan sungai dengan kurva durasi debit.
Badan Pertanahan Nasional. (2012). Peta Tata Guna Lahan Wilayah Jawa Barat. Badan Pertanahan Nasional Provinsi Jawa Barat, Kementerian Agraria dan Tata Ruang

Bakhtiar, Hadihardaja, J. \& Hadihardaja, I.K., (2013). Pengaruh Curah Hujan Rata-rata Tahunan terhadap Indeks Erosi dan Umur Waduk pada DAS Citarum Hulu. Jurnal Media Komunikasi Teknik Sipil, vol. 19, no. 1:41-53. https://doi.org/10.14710/mkts.v19i1.7834

Choudhari, K., Panigrahi, B. \& Paul, J. C. (2014). Simulation of rainfall-runoff process using HECHMS model for Balijore Nala watershed Odisha India. International Journal of Geomatics And Geosciences, Volume 5 (2):253-265

Cunge, J. A. (1969). On the subject of a flood propagation computation method (Muskingum method). Journal of Hydraulic Research, Vol. 7(2):205-230

Kabiri, R., Chan, A. \& Bai, R. (2013). Comparison of SCS and Green-Ampt Methods In Surface RunoffFlooding Simulation For Klang Watershed In Malaysia. Open Journal of Modern Hydrology, Volume 3:102-114.

http://dx.doi.org /10.4236/ojmh.2013.33014

U.S. Department of Agriculture (2010) Keys to Soil Taxonomy, Eleventh Edition

ftp://ftpfc.sc.egov.usda.gov/NSSC/Soil_Taxono my/keys/2010_Keys_to_Soil_Taxonomy.pdf

Miller, W.A., \& Cunge, J.A. (1975). Simplified equation of unsteady flow, in Mahmood, K., \& Yevjevich, V. (eds.). (1975). Unsteady flow in open channels. Water Resources Publications:223-251 
Nilda, Adnyana, I. W. S., \& Merit, I. N., (2015). Analisis Perubahan Penggunaan Lahan Dan Dampaknya Terhadap Hasil Air di DAS Cisadane Hulu. Jurnal Ecotrophic, Vol. 9 (1): 35-45

Pérez-Sánchez, M., Sanchez-Romero, F., Ramos, H. \& López-Jimémenz, P. (2017). Calibrating a flow model in an irrigation network: Case study in Alicante, Spain. Spanish Journal of Agricultural Research,15(1), e1202.

https://doi.org/10.5424/sjar/2017151-10144.

Ponce, V. M. \& Yevjevich, V. (1978). MuskingumCunge method with variable parameters, Journal of the Hydraulics Division, ASCE, Vol. 104 (HY12), :1663-1667

Ponce, V.M. (1986). Diffusion wave modeling of catchment dynamics. Journal of the Hydraulics Division, ASCE, Vol 112(8):716-727

Pusat Penelitian dan Pengembangan Sumber Daya Air. (2017). Buku Data Debit Sungai Nasional. Laporan Komponen Output DIPA Tahun 2018. Kementerian Pekerjaan Umum dan Perumahan Rakyat (Tidak dipublikasi).
Pusat Penelitian dan Pengembangan Sumber Daya Air. (2017). Buku Data Hujan Nasional. Laporan Komponen Output DIPA Tahun 2018. Kementerian Pekerjaan Umum dan Perumahan Rakyat (Tidak dipublikasi).

Suprapto, M., Irwani, Y. \& Qomariyah, S. (2016) Prediksi Pasok Dan Kebutuhan Air Sungai Ciliwung Pada Ruas Jembatan Panus Sampai Manggarai, e-Jurnal Matriks Teknik Sipil: 388

Syahputra, I. (2015). Kajian Hidrologi dan Analisa Kapasitas Tampang Sungai Krueng Langsa Berbasis HEC-HMS Dan HEC-RAS. Jurnal Teknik Sipil Unaya, Volume 1, No. 1: 15-28

US Army Corps of Engineers. (2000). Technical Reference Manual Hydrologic Modelling System. Washington DC

\section{LAMPIRAN}

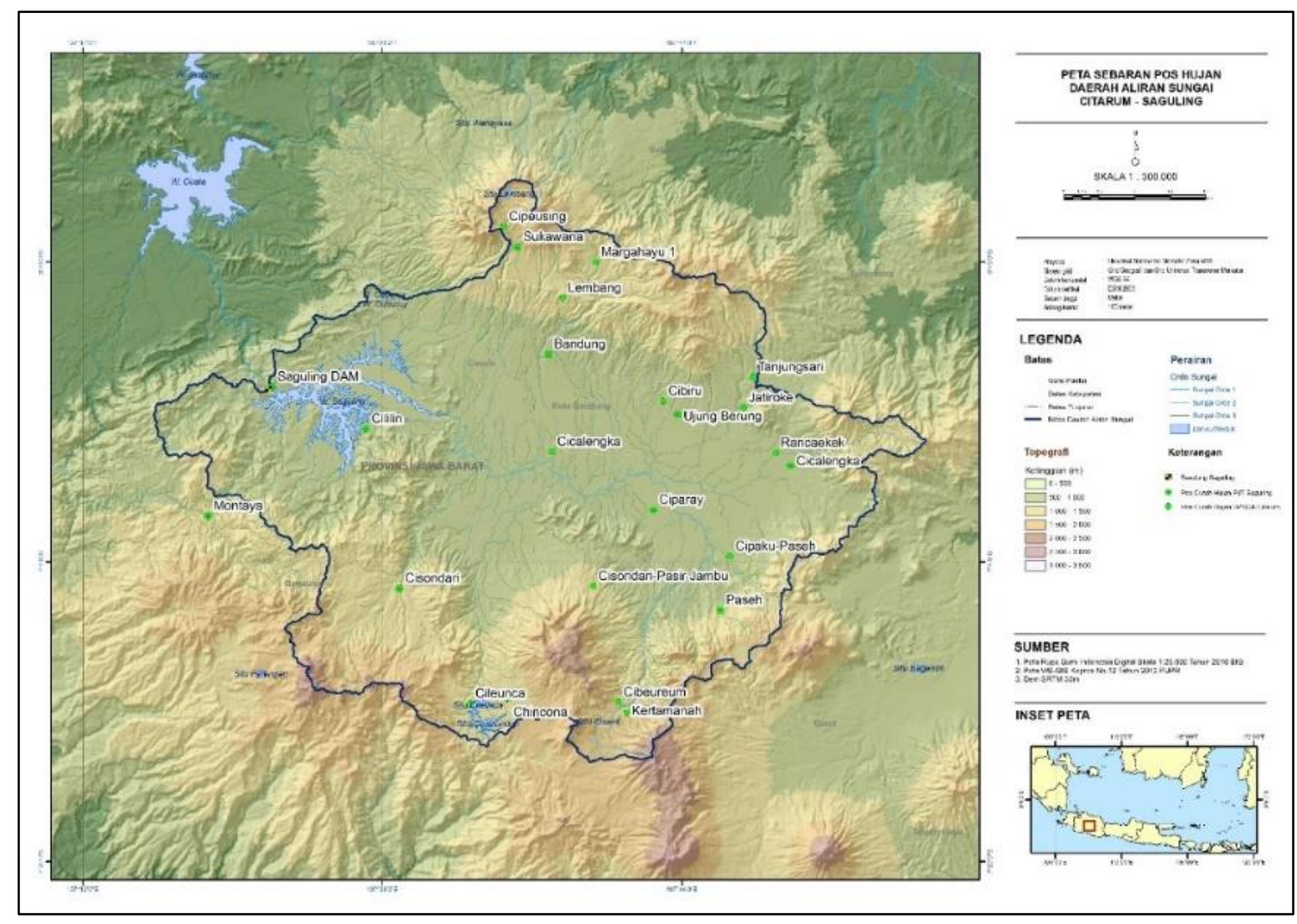

Sumber: Hasil analisis

Gambar L-1 Distribusi Penyebaran Pos Hujan di DAS Waduk Saguling 
Tabel L-1 Daftar Pos Hujan di dalam dan sekitar DAS Waduk Saguling

\begin{tabular}{|c|c|c|c|c|c|c|c|c|c|c|c|c|c|c|c|c|c|c|c|c|c|c|}
\hline \multirow{2}{*}{ No. } & \multirow{2}{*}{ Nama Pos } & \multicolumn{2}{|c|}{ Koordinat } & \multirow{2}{*}{ Pemilik } & \multicolumn{2}{|c|}{$198 \ldots$} & \multicolumn{6}{|c|}{$199 \ldots$} & \multicolumn{6}{|c|}{$200 \ldots$} & \multicolumn{3}{|c|}{$201 \ldots$} & \multirow{2}{*}{\begin{tabular}{|l} 
Jumlah \\
Tahun \\
\end{tabular}} \\
\hline & & $\mathrm{Y}$ & $x$ & & 67 & 89 & 0 & 12 & 34 & 45 & 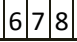 & 9 & $\begin{array}{llll}0 & 1 & 2 \\
\end{array}$ & 23 & $\begin{array}{lll}3 & 4 & 5 \\
\end{array}$ & \begin{tabular}{ll|l|}
5 & 6 & 7 \\
\end{tabular} & 85 & 90 & 12 & \begin{tabular}{|l|l|l}
2 & 3 & 4 \\
\end{tabular} & 567 & \\
\hline 1 & Cibeureum & -7.192 & 107.677 & \multirow{14}{*}{ BPSDA Citarum } & & & & & & & & & & & & & & & & & & 18 \\
\hline 2 & Cibiru & -6.924 & 107.716 & & & & & & & & & & & & & & & & & & & 14 \\
\hline 3 & Cileunca & -7.193 & 107.545 & & & & & & & & & & & & & & & & & & & 14 \\
\hline 4 & Cipaku - Paseh & -7.193 & 107.545 & & & & & & & & & & & & & & & & & & & 15 \\
\hline 5 & $\begin{array}{c}\text { Cipanas } \\
\text { Pangalengan }\end{array}$ & -7.062 & 107.776 & & & & & & & & & & & & & & & & & & & 14 \\
\hline 6 & Cipeusing & -6.769 & 107.575 & & & & & & & & & & & & & & & & & & & 14 \\
\hline 7 & $\begin{array}{c}\text { Cisondari Pasir } \\
\text { Jambu }\end{array}$ & -6.769 & 107.575 & & & & & & & & & & & & & & & & & & & 18 \\
\hline 8 & Jatiroke & -6.930 & 107.788 & & & & & & & & & & & & & & & & & & & 19 \\
\hline 9 & Kayu Ambon & -6.821 & 107.633 & & & & & & & & & & & & & & & & & & & 16 \\
\hline 10 & Kertamanah & -6.821 & 107.633 & & & & & & & & & & & & & & & & & & & 13 \\
\hline 11 & Lembang & -6.832 & 107.627 & & & & & & & & & & & & & & & & & & & 12 \\
\hline 12 & Margahayu I & -6.800 & 107.657 & & & & & & & & & & & & & & & & & & & 14 \\
\hline 13 & Rancaekek & -6.970 & 107.817 & & & & & & & & & & & & & & & & & & & 12 \\
\hline 14 & Tanjungsari & -6.903 & 107.796 & & & & & & & & & & & & & & & & & & & 14 \\
\hline 15 & Cicalengka & -6.969 & 107.618 & \multirow{11}{*}{ PT Indonesia Power } & & & & & & & & & & & & & & & & & & 27 \\
\hline 16 & Paseh & -6.800 & 107.657 & & & & & & & & & & & & & & & & & & & 27 \\
\hline 17 & Chincona & -6.883 & 107.614 & & & & & & & & & & & & & & & & & & & 25 \\
\hline 18 & Ciparay & -7.185 & 107.588 & & & & & & & & & & & & & & & & & & & 28 \\
\hline 19 & Ujung Berung & -6.903 & 107.796 & & & & & & & & & & & & & & & & & & & 27 \\
\hline 20 & Bandung & -6.883 & 107.614 & & & & & & & & & & & & & & & & & & & 27 \\
\hline 21 & Cililin & -7.193 & 107.545 & & & & & & & & & & & & & & & & & & & 27 \\
\hline 22 & Montaya & -6.800 & 107.657 & & & & & & & & & & & & & & & & & & & 24 \\
\hline 23 & Sukawana & -6.970 & 107.817 & & & & & & & & & & & & & & & & & & & 26 \\
\hline 24 & Saguling DAM & -6.970 & 107.817 & & & & & & & & & & & & & & & & & & & 26 \\
\hline 25 & Cisondari & -6.769 & 107.575 & & & & & & & & & & & & & & & & & & & 27 \\
\hline
\end{tabular}

Sumber data: Pusat Penelitian dan Pengembangan Sumber Daya Air (2017) keterangan:

\footnotetext{
Data lengkap 12 bulan

Data kurang dari 12 bulan
} 


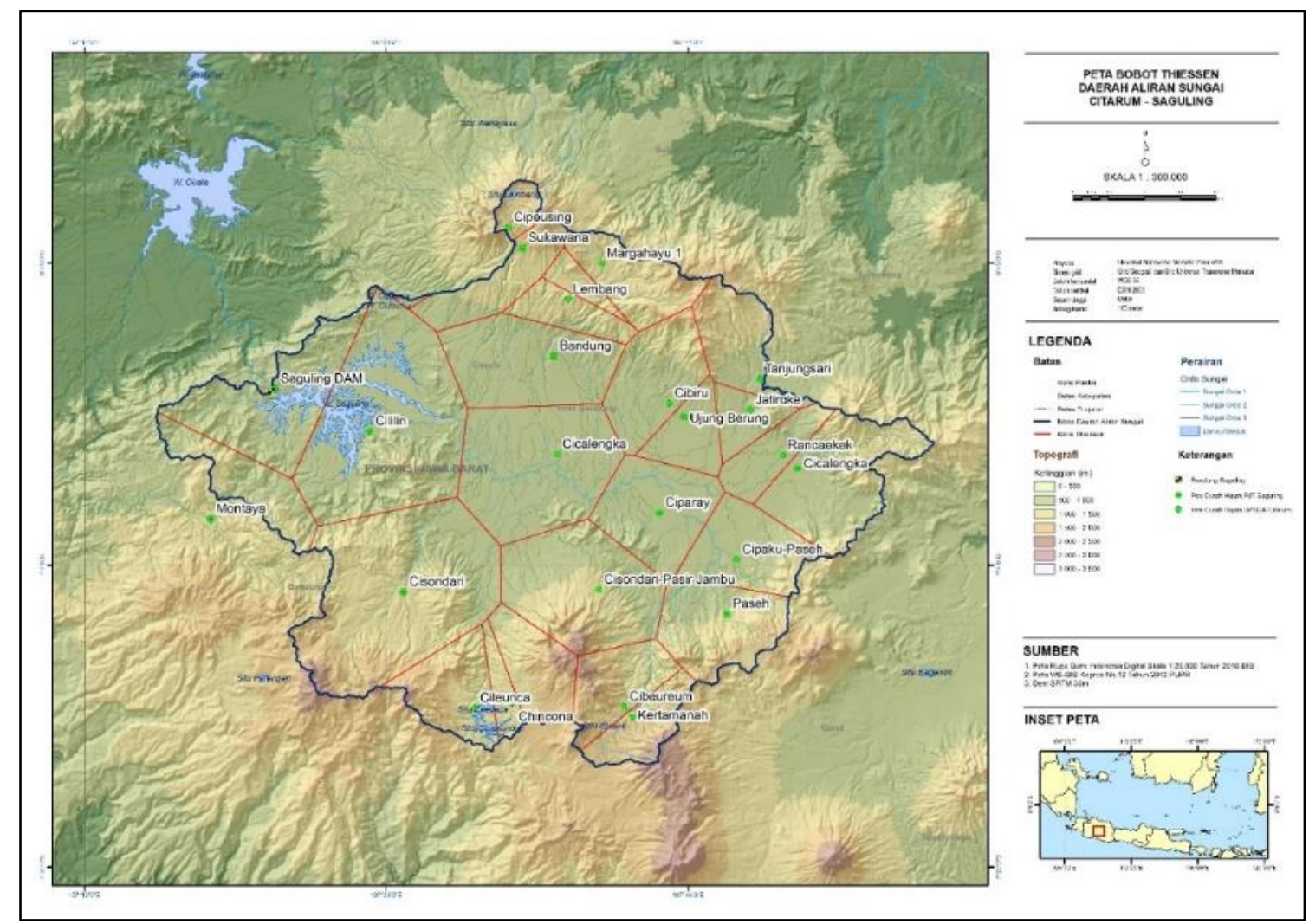

Gambar L-2 Poligon Thiessen untuk DAS Waduk Saguling

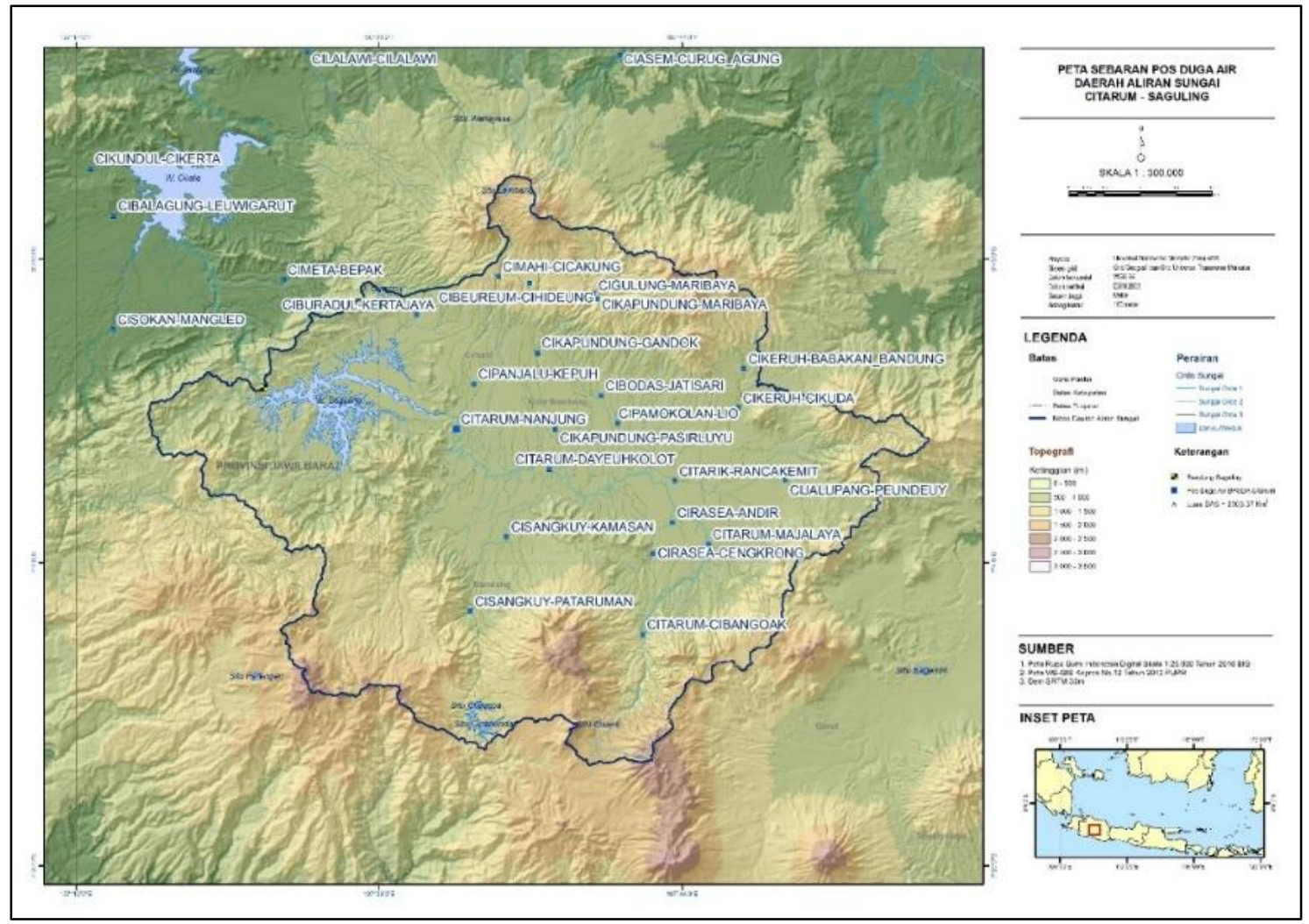

Gambar L-3 Distribusi Penyebaran Pos Duga Air di DAS Waduk Saguling 